\title{
Immunostimulatory activity of Stachys mialhesi de Noé
}

\author{
Assia Benmebarek ${ }^{*}$, Sakina Zerizer ${ }^{1}$, Souheila Laggoune $^{2}$ and Zahia Kabouche $^{2}$
}

\begin{abstract}
Background: Immunostimulatory therapy is now being recognized as an alternative to conventional chemotherapy for a variety of disease conditions, involving the impaired immune response of the host. In the present study, the immunostimulatory effect of the butanolic extract obtained from S. mialhesi aerial parts, was evaluated in vivo.

Methods: The immunostimulant potential of the plant extract on the phagocytic activity was measured by the carbon clearance rate test.

Results: Our research revealed that at different doses (50, 100 and $500 \mathrm{mg} / \mathrm{kg})$, S. mialhesi extract increased the phagocytic activity in a dose dependant manner when compared with the control and thus the clearance rate of carbon was faster after the administration of the plant extract.
\end{abstract}

Conclusion: S. mialhesi extract exhibited a dose-dependent immunostimulant effect on the reticuloendothelial system, which could be attributed to the presence of active principles in this butanolic extract.

Keywords: Immunostimulatory activity, Phagocytic activity, Carbon clearance rate, Reticuloendothelial system, Stachys mialhesi de Noé

\section{Background}

Immunostimulators have been known to support T-cell function, activate macrophages, granulocytes, complement and natural killer cells apart from affecting the production of various effectors molecules generated by activated cells (Paraimmunity) [1].

It is expected that non-specific effects offer protection against different pathogens, including bacteria, fungi, and viruses and constitute an alternative to conventional chemotherapy [2].

Immunostimulatory therapy is now being recognized as an alternative to conventional chemotherapy for a variety of disease conditions, involving the impaired immune response of the host [3].

The genus Stachys (Lamiaceae) includes about 200 to 300 species in the world [4] and is considered to be one of the largest genera of this family. In Algeria, this genus is represented by 14 species including the endemic species S. mialhesi de Noé [5].

\footnotetext{
* Correspondence: assia.benmebarek@gmail.com

'Laboratoire de Génie microbiologie et application, Equipe: biologie moléculaire et cellulaire. Faculté des sciences, Université de Constantine 1 , Constantine, Algeria

Full list of author information is available at the end of the article
}

Pharmacological studies have confirmed that extract of plants belonging to the genus Stachys exert significant antibacterial, anti-inflammatory, antitoxic, anti-nephritic, antihepatitis, anti-anoxia and hypotensive activity, antispasmodic, anti-asthma and anti-rheumatic activities [6] and [7].

In Iran, the aerial parts of S. inflata Benth are used to treat infection, asthma, rheumatic and other inflammatory disorders [8]. S. lavandulifolia Vahl was used as an anxiolytic and sedative [9].

The study of [10] showed inhibitory effects of S. obtusicrena on both cellular and humoral immune responses and suggests that this effect may in part be due to the induction of apoptosis in proliferative lymphocytes.

The stimulation index of all cultures treated with different concentrations of the extract of S. obtusicrena was less than 1 [10].

The present investigation was undertaken to evaluate the immunostimulatory effect of the butanolic extract obtained from the aerial parts of $S$. mialhesi, using in vivo model.

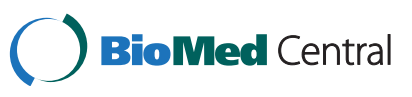

(c) 2013 Benmebarek et al.; licensee BioMed Central Ltd. This is an Open Access article distributed under the terms of the Creative Commons Attribution License (http://creativecommons.org/licenses/by/2.0), which permits unrestricted use, distribution, and reproduction in any medium, provided the original work is properly cited. 


\section{Materials and methods Plant material}

Aerial parts of S. mialhesi de Noé were collected in April 2005 at Djebel El-Ouahch Constantine (North Eastern Algerian). The voucher specimen was identified by Professor Gérard De Bélair (University Badji-Mokhtar, Annaba) and was deposited at the Musée botanique de la Ville d'Angers (France) under the reference MBAng2005.10.

\section{Preparation of the extract}

Air-dried and powdered aerial parts $(1 \mathrm{~kg})$ of S. mialhesi were extracted with $70 \% \mathrm{MeOH}$. The residue was suspended in water and extracted successively with petroleum ether, dichloromethane, ethylacetate and $\mathrm{n}-\mathrm{BuOH}$.

\section{Animals}

Adult male Mus Musculus mice (2.5- 3 month old) from central pharmacy Algeria, weighing (25-36 g) were used for determination of the phagocytic activity. The animals were kept under standard laboratory conditions of humidity, temperature $\left(25 \pm 1^{\circ} \mathrm{C}\right)$ and light $(12 \mathrm{~h}$ day: $12 \mathrm{~h}$ night), and allowed free access to food and water.

\section{Phagocytic activity}

The clearance rate of carbon was measured by the method of [11].

Animals were divided into four groups, consisting of 5 mice in GI, GII and GIV but the GIII consisting of 4 mice. Group I (Control) was given $0.9 \% \mathrm{NaCl}(0.5 \mathrm{ml} /$ mouse, i.p), groups II, III and IV were administered by i.p injection with different concentrations of $S$. mialhesi extract $(50,100$ and $500 \mathrm{mg} / \mathrm{kg}$ ) respectively.

After 48 h of i.p injection, the mice were administered with carbon ink suspension at a dose of $0.1 \mathrm{ml} / 10 \mathrm{~g}$ through the tail vein; the mixture consisted of black carbon ink $3 \mathrm{ml}$, saline $4 \mathrm{ml}$ and 3\% gelatin solution $4 \mathrm{ml}$.

Blood samples were taken from the retro orbital vein by using glass capillaries, at 5 and $15 \mathrm{~min}$. Blood sample drops (14) were mixed with $0.1 \%$ sodium carbonate solution $(4 \mathrm{ml})$ for the lysis of erythrocytes and the absorbance measured at $675 \mathrm{~nm}$ using a spectrophotometer.

The phagocytic activity is expressed by the phagocytic index $\mathrm{K}$ which measures all the reticuloendothelial system function in the contact with the circulating blood. The clearance rate is expressed as the half-life period of the carbon in the blood $\left(t_{1 / 2}, \mathrm{~min}\right)$. These are calculated by means of the following equations:

$$
K=\frac{\left(\operatorname{lnOD}_{1}-\operatorname{lnOD}_{2}\right)}{\left(t_{2}-t_{1}\right)}, t_{1 / 2}=0.693 / K
$$

Where $\mathrm{OD}_{1}$ and $\mathrm{OD}_{2}$ are the optical densities at times $t_{1}$ and $t_{2}$ respectively.

\section{Statistical analyses}

Results were analyzed for differences between the groups across dietary treatments by one -way ANOVA test and Tukey's multiple comparison tests (SPSS version 9).

\section{Results}

Effect of $S$. mialhesi extract on the phagocytic activity and the carbon clearance rate is shown in Table 1.

The present data showed that there is a difference in the means for the phagocytic index $(\mathrm{K})$ between groups (GI, GII, GIII and GIV) $\mathrm{P}=0,058$ and the group IV is significantly different from $\mathrm{GI}$ at $\mathrm{P}=0,041$.

This indicates that $S$. mialhesi extract enhanced the phagocytic activity by stimulating the reticuloendothelial system in a dose dependant manner (Figure 1).

As shown in Figure 2, the clearance rate of carbon was faster after $48 \mathrm{~h}$ but not significantly between (GI, GII, GIII and GIV) groups $\mathrm{P}=0,149$.

Pearson correlation of phagocytic index $(\mathrm{K})$ and carbon clearance $=-0,570$ and $\mathrm{P}=0,011$.

This indicates that the extract shows carbon clearance enhancing activity and affirms that $S$. mialhesi extract enhanced the phagocytic activity.

\section{Discussion}

The reticuloendothelial system is clearing particulate substances, such as bacteria, and altered endogenous materials, such as fibrin aggregates [12]. Phagocytosis is the mechanism by which microorganisms and foreign bodies, dead or injured cells are removed.

Measurement of the activity of the reticuloendothelial system depends upon estimation of the rate of clearance from the blood of foreign materials, such as colloidal carbon [12].

Treatment by $S$. mialhesi extract enhanced the rate of carbon clearance from the blood when compared to the control group. This reflects the enhancement of the phagocytic activity of mononuclear macrophage and nonspecific immunity, which includes opsonisation of the foreign particulate matter with antibodies and complement $\mathrm{C} 3 \mathrm{~b}$, leading to a more rapid clearance of foreign particulate matter from the blood [13].

[14] demonstrated that cocoa polyphenols are powerful stimulators of the innate immune system and the first reaction of the adaptive immunity. The immunostimulatory effect was showed following the isolation and culture of purified monocytes, CD4 and CD8 cells in the presence of cocoa polyphenols and after they were confronted with lipopolysaccharides.

Our results revealed that $S$. mialhesi extract appeared to stimulate the phagocytic activity by increasing the clearance rate of carbon by the cells of the reticuloendothelial system. This is due to the fact that it contains natural 
Table 1 Effect of S. mialhesi extract on the phagocytic activity and the clearance rate of carbon from the circulating blood of mice

\begin{tabular}{|c|c|c|c|c|c|c|}
\hline Treatment groups & Dose & $\begin{array}{l}\text { Number of } \\
\text { mice }\end{array}$ & $\begin{array}{l}\text { Phagocytic } \\
\text { index K }\end{array}$ & $\begin{array}{l}\text { Average phagocytic } \\
\text { index } K^{a}\end{array}$ & $\begin{array}{c}\text { Carbon clearance rate } \\
\left(t_{1 / 2}, \mathrm{~min}\right)\end{array}$ & $\begin{array}{l}\text { Average Carbon clearance rate } \\
\left(\mathrm{t}_{1 / 2}, \mathrm{~min}\right)\end{array}$ \\
\hline \multirow[t]{5}{*}{ Group I Control (Saline) } & \multirow[t]{5}{*}{$0.5 \mathrm{ml}$} & \multirow[t]{5}{*}{5} & 0.0063 & \multirow{5}{*}{$\begin{array}{c}0.032^{(d)} \pm \\
0.01\end{array}$} & 110 & \multirow[t]{5}{*}{$41.18^{b)} \pm 18,27$} \\
\hline & & & 0.015 & & 46.2 & \\
\hline & & & 0.028 & & 24.75 & \\
\hline & & & 0.054 & & 12.83 & \\
\hline & & & 0.057 & & 12.15 & \\
\hline \multirow[t]{5}{*}{ Group II } & \multirow[t]{5}{*}{$50 \mathrm{mg} / \mathrm{kg}$} & \multirow[t]{5}{*}{5} & 0.013 & \multirow[t]{5}{*}{$0.080 \pm 0.32^{c)}$} & 53.30 & \multirow[t]{5}{*}{$19.66^{b} \pm 9,07$} \\
\hline & & & 0.029 & & 23.89 & \\
\hline & & & 0.072 & & 9.62 & \\
\hline & & & 0.086 & & 8.05 & \\
\hline & & & 0.20 & & 3.46 & \\
\hline \multirow[t]{4}{*}{ Group III } & \multirow[t]{4}{*}{$100 \mathrm{mg} / \mathrm{kg}$} & \multirow[t]{4}{*}{4} & 0.11 & \multirow[t]{4}{*}{$0,063 \pm 0.015^{c}$} & 6.3 & \multirow[t]{4}{*}{$12,55^{b} \pm 2,17$} \\
\hline & & & 0.043 & & 16.11 & \\
\hline & & & 0.047 & & 14.74 & \\
\hline & & & 0.053 & & 13.07 & \\
\hline \multirow[t]{5}{*}{ Group IV } & \multirow[t]{5}{*}{$500 \mathrm{mg} / \mathrm{kg}$} & \multirow[t]{5}{*}{5} & 0.085 & \multirow[t]{5}{*}{$0.138 \pm 0.032^{\text {cdd }}$} & 8.15 & \multirow[t]{5}{*}{$5.97^{b} \pm 1,03$} \\
\hline & & & 0.097 & & 7.14 & \\
\hline & & & 0.10 & & 6.93 & \\
\hline & & & 0.15 & & 4.62 & \\
\hline & & & 0.26 & & 2.66 & \\
\hline
\end{tabular}

a) Each value represents the mean S.E. Difference from the control b) $p>0.05$ and c) $p=0,05$ and d) $p<0,05$.

physiologically active substances such as Terpenoids, Flavanoids and phenolic compounds [15].

\section{Conclusion}

Qualitative phytochemical analysis of the S. mialhesi extract revealed that it contains natural physiologically active substances such as Terpenoids, Flavanoids and phenolic compounds [15], and it is already reported that naturally occurring phenolic compounds have immunomodulatory activity [16].

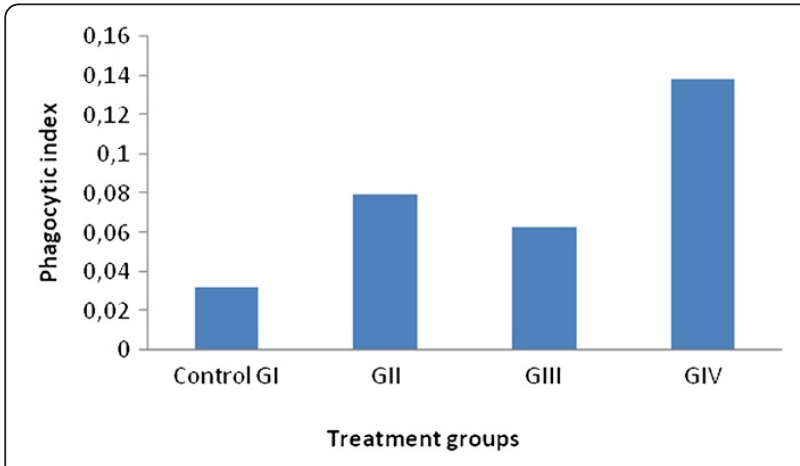

Figure 1 Effect of S. mialhesi extract on phagocytic activity.
The present study established that $S$. mialhesi extract stimulated non specific immune response of the animals by increasing the phagocytic activity, measured in terms of phagocytic index and this could be attributed to its natural components.

This stimulation indicates the presence of active principles in the $S$. mialhesi extract. The active principles responsible for the stimulatory effect are yet to be identified.

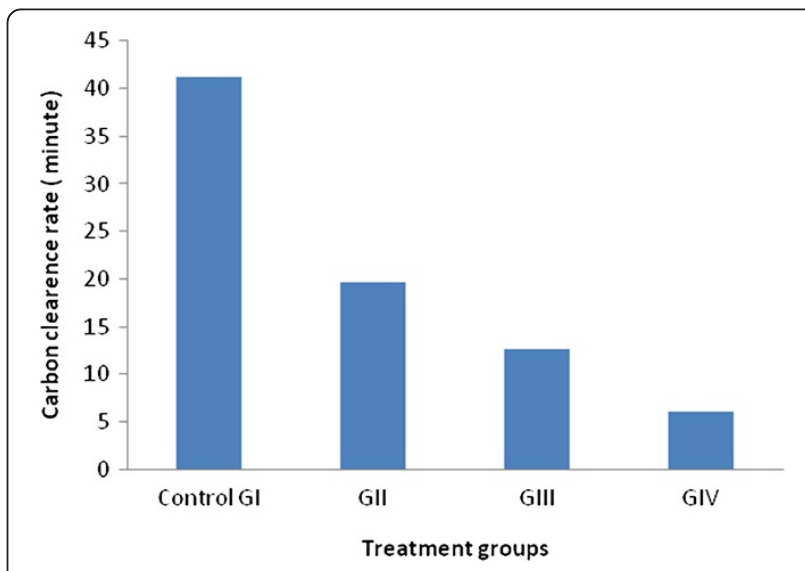

Figure 2 Effect of S. mialhesi extract on the carbon clearance rate 


\section{Abbreviations}

Ip: Intraperitoneal; S: Stachys.

\section{Competing interests}

The authors declare that they have no competing interests.

\section{Authors' contributions}

$A B$ and $S Z$ carried out the studies, acquired data, performed data analysis, drafted and revised the manuscript, and played a major role in all the experimental procedures of this study. SL and ZK carried out the phytochemical part. All authors read and approved the final manuscript.

\section{Acknowledgement}

The authors are grateful to the DG-RSDT at the MESRS (Ministery of Scientific Research, Algeria) for the financial support.

\section{Author details}

${ }^{1}$ Laboratoire de Génie microbiologie et application, Equipe: biologie moléculaire et cellulaire. Faculté des sciences, Université de Constantine 1, Constantine, Algeria. ${ }^{2}$ Laboratoire d'obtention de substances thérapeutiques (Lost), Université de- Constantine 1, Laboratoire d'Obtention de Substances Thérapeutiques (L.O.S.T), Campus Chaabat Ersas, Constantine 25000, Algeria.

Received: 24 July 2012 Accepted: 2 January 2013

Published: 11 January 2013

\section{References}

1. Wagner $\mathrm{H}$, Kraus $\mathrm{H}$, Jurcic $\mathrm{K}$ : Search for potent immunostimulating agents from plants and other natural sources. In Immunomodulatory agents from plants. 1st edition. Edited by Wagner H. Switzerland: Birkashauser verlag Basel; 2003:1-6.

2. Atal CK, Sharma ML, Khariya A: Immunomodulating agents of plant origin. J Ethnopharmacol 1986, 18:133-141.

3. Upadhaya SN: Therapeutic Potential of Immunomodulatory Agents from Plant products. In Immunomodulation. 1st edition. Edited by Upadhaya SN. New Delhi: Narosa publishing house; 1997:149-150.

4. Rechinger KH, Hedge IC: Flora Iranica. Graz Austria: Akademiche Druck Verlagsanstalt; 1982:360-361.

5. Quezel P, Santa S: Nouvelle Flore de l'Algérie et des Régions Désertiques Méridionales. Paris: C.N.R.S; 1962:815-816.

6. Makhlouf AA, Maklad YA, Ahmed AE: Synthesis and analgesic anti inflammatory activities of some 1,2, 4 triazine derivatives New Egypt. $J$ Med 2002, 26:213.

7. Vongtau HO, Abbah J, Ngazal IE, Kunle OF, Chindo BA, Otsapa PB, Gamaniel KS: Antinociceptive and anti-inflammatory activities of the methanolic of Parinari polyandra stem bark in rats and mice. J Ethnopharmacol 2004, 90:115-121.

8. Maleki N, Garjani A, Nazemiyah H, Nilfouroushan N, Eftekhar Sadat AT, Allameh Z, Hasannia N: Potents anti-inflammatory activities of hydroalcoholic extract from aerial parts of Stachys Inflata on rats. J Ethnopharm 2001, 75:213-218.

9. Amin G: Popular medicinal plants of Iran. Tehran: Iranian Research Institute of Medicinal Plants; 1991:80.

10. Amirghofran Z, Bahmani M, Azadmehr A, Javidnia K. Immunomodulatory and apoptotic effects of Stachys obtusicrena on proliferative lymphocytes. Medical science monitor 2007, 13(6):BR145-BR150.

11. Biozzi G, Benacerraf B, Halperm BN: Br J Exp Pathol 1953, 34:441.

12. Sigurd J, Normann MD, Earl P, Benditt MD: Function of the reticuloendothelial System. Seattle: Department of Pathology, University of Washingt; 1965:693-707.

13. Furthvan R, Bergvanden BM: Clinical immunology. 1st edition. London: Gower Medical Publishing; 1991:67.

14. Sener $G$, et al: Protective effect of beta-glucan against oxidative organ injury in a rat model of sepsis. Int Immunopharmacol 2005:1387-1396.

15. Laggoune S, Zeghib A, Kabouche A, Kabouche Z, Maklad YA, Leon F, Brouard I, Bermejo J, Calliste CA, Duroux JL: Components and antioxidant, anti-inflammatory, anti-ulcer and antinociceptive activities of the endemic species Stachys mialhesi de Noe. Arabian Journal of Chemistry 2011, 4:361-377.

16. Neha J, Mishra RN: Immunomodulator activity of Trikatu mega Ext. International Journal of Research in Pharmaceutical and Biomedical Sciences 2011:160-164.

doi:10.1186/1710-1492-9-2

Cite this article as: Benmebarek et al.: Immunostimulatory activity of Stachys mialhesi de Noé. Allergy, Asthma \& Clinical Immunology 2013 9:2.

\section{Submit your next manuscript to BioMed Central and take full advantage of:}

- Convenient online submission

- Thorough peer review

- No space constraints or color figure charges

- Immediate publication on acceptance

- Inclusion in PubMed, CAS, Scopus and Google Scholar

- Research which is freely available for redistribution 